\title{
GENRE SPECIFICITY OF NARRATIVITY OF THE PAST IN UKRAINIAN RETELLINGS AND HISTORICAL SONGS
}

\section{Pavlenko I. Ya.}

\section{INTRODUCTION}

In the modern study of folklore the statement that, with the development of school education, mass media and digital technologies the loss of mnemonic memory's functions by the folklore occur, became an axiom and so, the creation of the great variety of folklore genres fades, the translation of which was called forth by the necessity of preserving and conveying the memory about the past. That is why during the XIX century the area of circulation of ballad was narrowing, gradually it was out of kobza-payers' active repertoire, the creation of new historical songs ceased and the old ones started to be forgotten. There existed quite a few of historical legends and retellings, but in the second half of the XX century the circle of experts and talented performers of these genres narrowed, very frequently the texts were not given over even in the frames of the family. The traditional oral transmission was replaced by the oral-written one in the process of immediate communication, and recently, with the growth of the interest to the national culture, oral-written-oral one, which also not fully corresponds with the tradition, but gives the possibility not to lose it once and for all.

"Historical" genres of Ukrainian folklore such as ballades, historical songs, historical legends and translations, time and again became the object of the collection, publishing and scientific reflexion. Moreover, the theoretical comprehension, at first, took place simultaneously with the gathering and publishing of the material and was based on the actively occurring folklore material, usually in the form of prefaces and comments to the collected material. The modern study of folklore appeals, mostly, to the earlier stated works. The existence of the text and it's interpretations in different time levels reveals string of problems. The main ones are the change of the contextual knowledge, the different character of the events and main heroes' perception, which are spoken about in the folklore narratives, the impossibility of clarification, the absence of non-verbal means, which are peculiar to the non-contact communication and add new 
connotation, etc. The analysis of the previous folklore tradition should also foresee the growth of the epic distance, and, accordingly, the difference of the conception of the world of those, who sang/told about the past formerly, and of those, who has now read and has sung over again/has told once more or reinterpreted the material.

As the time passes, the great part of the active functioning folklore material has been lost, on the conditions of the permanent emphasis of different historical periods, persons and events in the Ukrainian humanitarian and, first of all, informational space, the question s about the next facts arises, how did the people fell and recreate their contemporaneity (any plot of the "historical" folklore work starts with the reflexion of some specific event), what did they choose for preserving and rendering to the next generations, how was the past apprehended by the representatives of the former generations, what and where (territorially) was remembered, who and why was made a hero or was demonized.

The folklore-historical memory was transmitted via songs (the ballade, the historical song) and prose genres the historical legend and the retelling). The publishing of the collections according to this principle ${ }^{1}$ became the general practice, also the study of the genre system of folklore causes the separate investigation of the song and prose epics, and moreover of the epic prose ${ }^{2}$ and song epic and lyrical-epical works

${ }^{1}$ For example : Українські думи та історичні пісні. Москва : Укрдержвидав, 1944 ; Українські народні думи та історичні пісні. Київ : Вид-во АН УРСР, 1955. 655 с. ; Українські народні казки, легенди, анекдоти : хрестоматія. Київ : Держлітвидав, 1957. 543 с. ; Легенди та перекази. Київ : Наукова думка, 1985 ; Писана керниця : топонімічні легенди та перекази українців Карпат. Львів : Інститут народознавства НАНУ, 1994; Народні легенди та перекази українців Карпат. Київ : Наукова думка, 1995 ; Січова скарбниця : легенди та перекази Нижньої Наддніпрянщини. Запоріжжя : ЗДУ, 1999. 392 с. тощо.

${ }^{2}$ For example : Сухобрус Г. Легенди і перекази. Украйнська народна поетична творчість. Київ : Радянська школа, 1965. С. 161-171 ; Сокіл Василь. Народні легенди та перекази українців Карпат. Київ : Наукова думка, 1995. 158 с. ; Дунасвська Л. Легенди та перекази. Украӥнська народнопоетична творчість / М. Грицай, В. Бойко, Л. Дунаєвська. Київ : Вища школа, 1985. С. 242-253; Давидюк В. Голос німого дзвона. Золота скриня: народні легенди перекази з Північної Волині й Західного Полісся. Луцьк : Вежа, 1996. С. 3-9; Павленко І. Легенди та перекази Нижньої Наддніпрянщини : буття у просторі та часі. Запоріжжя : ЗНУ, 2006. 243 c. 
of literature ${ }^{3}$. Accordingly, the comparison is usually made, mostly, in the frames of the related genres.

The materials of the poligenre folklore collections about the person or hero ${ }^{4}$ or about some event ${ }^{5}$, accumulated in the archives materials, modern field notes give the great material for the poliaspect comparisons. And, although, there exist works, which study the diversity of the representation of one or the other historical phenomena or ideas about some historical person in the folklore ${ }^{6}$, but the question about the character of interrelation of functions, literary world and the specificity of historical methods of genres of national prose and songs was not raised.

The analysis of the literary world, interpretations of the past and of the hero's of the folklore narrative works with historical theme character assures the necessity and relevance of the comparative study of the retellings and historical songs, which became the aim of this thesis, the topicality of which is the absence of the generalized works on the genre specificity of the verbalization of the past in the folklore works, which are orientated, first of all, to the preserving of the precise (on condition of the oral communication and the transmission between different generations) memory about the significant event and person.

3 Напр. : Березовський I., Родіна М., Хоменко В. Історичні пісні українського народу. Історичні пісні / упоряд. : І. Березовський, М. Родіна, В. Хоменко ; нотн. матеріал упор. А. Гуменюк ; за ред. М. Рильського, К. Гуслистого. Київ : Вид-во Академії наук Української РСР, 1961. С. 7-62 ; Хоменко В. Історичні пісні. Українська народна поетична творчість. Київ : Радянська школа, 1965. С. 209-234 ; Павленко I. Історичні пісні Запорожжя : регіональні особливості та шляхи розвитку. Запоріжжя : Тандем-У, 2003. 202 с.

${ }^{4}$ Напр., Народ про Довбуша : збірник фольклорних творів. Київ : Наукова думка, 1965. 304 с. ; Народ про Кармелюка : збірник фольклорних творів. Київ : Вид-во Академії наук Української РСР, 1961. 276 с.; Ходили опришки : збірник. Ужгород : Карпати, 1983. $384 \mathrm{c}$.

${ }_{6}^{5}$ Джерела про зруйнування Запорозької Січі. Львів : Афіша, 2005. 127 с.

6 Напр., Мишанич С., Кейда Ф. Гайдамаки та опришки виразники національно-визвольних змагань українського народу. Донецьк: Касіопея, 1995. 101 с. ; Кейда Ф., Мишанич С. Народні месники України у фольклорі : монографія. Донецьк : Кассіопея, 1998. 113 с. ; Кейда Ф. Український фольклор про гайдамаччину : монографія. Київ : Вирій, 1999. 240 с. ; Будівський П. Олекса Довбуш в історії, фольклорі та літературі (проблеми історичної та художньої правди) : монографія. Київ : Бланк-Сервіс, 1999. 496 с. ; Коновалова М. Гетьман Мазепа у фольклорі і літературі : автореф. дис. ... канд. філол. наук. Львів, 2001. 16 с. 


\section{The genre and history: problems of correlation}

In recent years there exist completely different thoughts about the fact, how the historical memory is recreated in folklore. The works about:

1) the history, event or biography (some its elements) of the historical person are recreated in the literary or even half-documentary form (the point of view, which is peculiar to the scientists, the methodology of the analysis of which tends to the traditional cultural-historic school);

2) so-called historical genres are the designing of new meanings, giving the new connotations to the past, from the position of the present time (such vision is peculiar to the representatives of the structuralsemiotic approach);

3 ) the cultural memory is fundamentally antihistorical, total mythologization of the past occurs (the point of view of M. Eliade and his followers).

In the forming of personal point of view at this question, the fundamental is the definition of the genre of the piece of literature, as, according to B. Putilov, the character of historism, the form of "work" of collective memory in different genres, is not the same, the history "is presented from different angles, by different spheres, with different problems. The character of the historical interest itself is different. The folklore is, as if, divided between different genres "duties", "singled out" to each genre its specific sphere, its circle of problems, its ways of solutions" .

Terms "historical song" and "retelling" are traditional for humanitarian sciences, but the paradox of the modern folklore study lies in the fact, that the great amount of its main concepts is degraded, and sometimes is not worked out. Almost everybody use the terminology, which seems to be fixed but, one and the same terms are often used to denote different phenomena. The necessity of folkloristics thesaurus' regulation has been the urgent requirement for a long time, as the existing vocabularies do not completely solve the problems of definitions. The same concerns the definitions of genres, as the usage of the term, mentioned above, varies in the scientific discourse.

Each narrative folklore piece of work is, according to its essence, the functional world view, as far as it is artistically assimilated and recreated, transformed reality. The main peculiarities of this literary world are the non-identity with the initial reality, the participation of fantasy and fiction in its creation, the possibility to use not only existing but also

7 Путилов Б. Типология фольклорного историзма. Типология народного эпоса : сборник статей. Москва : Наука, 1975. С. 165. 
conventional forms of representation. As long as the genre is the whole of literary works with typologically identical comprehension and recreation of various types of reality's sides, it is possible to speak about world views peculiar to some specific genres. The most essential components of the genre world view are characters and events, and also time and space of the hero and his reality and also the outlook at them.

We assume, that the world view itself, in all its main constituents and specific «outer orientation» (according to M. Bakhtin ${ }^{8}$ ), the main factors of which are the social-domestic function, some specific surrounding of the creation and transmission, are the key traits of genre creation, when it goes about the narrative genres of folklore. That is why, for the analysis of the character of the representation of the past in frames of texts of different genres and types and rhythm-building structures, it is reasonable to address to their generalized world view, and thus to study the character of the actant (both the hero and the antithetic), the time, the space, the event and its results, the means and specificity of their depiction depending on the «genre» outlook, social functions of the genres under analysis.

In this thesis, speaking about the genre nature of the folklore narrative and historical memory, we take into account facts that:

1) each literary work, and moreover those, which are in the group of typologically related, can be characterized by genre-creating (dominant) and accompanying (variant) traits;

2) it is necessary to point out dominant traits of the genre, as far as one or the other system of characteristics, which it taken as the basis, may include both qualities, and sometimes substitute the dominant ones with accompanying (genre-creating, variant) ones.

Such approach makes it possible to specify genre definitions and choose the correct material for the further comparison and detection of the genre specificity of the representation of the past.

The east-Slavic folklore study in general and the Ukrainian one in particular, is characterized by the tradition to study the problem of the genre specificity of the retelling in comparison with the legend ${ }^{9}$. Such approach is represented both in educative practice and in the scientific

${ }^{8}$ Медведев П. (Бахтин М.) Формальный метод в литературоведении : Критическое введение в социологическую поэтику. Москва : Лабиринт, 2003. (Бахтин под маской. Вып. 2). С. 145.

${ }^{9}$ Павленко I. Легенда та переказ в українському фольклорі : до проблеми дефініцій. Мова і культура : науковий журнал. Київ : Видавничий дім Дмитра Бураго, 2007. Вип. 9. Т. VIII (96). С. 5-13. 
discourse. Although, the clear idea about the historical retelling was represented in the collection of works by P. Kulish "The Ukrainian national retellings", where the homogeneous material, according the reality's relation, is published, which corresponds to ideas about the retelling as the national historical memory, which exists in the form of non-published oral word ${ }^{10}$.

The modern level of the problem's investigation shows that, the genre-creating traits of the retelling are distinguished in comparison to the legend. For example, in works by G. Sukhobrus, the retellings were determined as "realistic oral tales about exclusively important life facts and situations. Comparing to the legends, the retellings are distinguished by the more documental content, more realistic literary means. <..> there is no hyperbolical representation. The retellings, which were created without delay, contain, first of all, the reliable facts about events" $"$. So, the differentiation of genres, from the point of view of the researcher, is possible according the opposition real/poetical attitude to the history and the reality in general, which causes the difference between the world views (or at least of its main components) of these two genres of the Ukrainian historical prose. The term "realistic" and its opposition to the poetic one, causes the objection in this system, as far as, independently of the storytellers' wish the primary reaction at the event and its designing into the verbal text are subjective. While in the process of the multiple transmission of the initial tale's text between different generations and/or locality it is transformed, differently structured, gets different expressive connotations, and finally, can be partially forgotten, and the knowledge which is absent is compensated for the fantasy. At the same time "more documental character" does not mean the actuality and confirmation by facts. Each text may contain some generalizations, stereotypical motives. etc., so we can speak only about the fictional "documental character" - the representation of not concrete, "real" phenomena, events and ideas about the character of their occurrence, but possible ones.

The main statement of the conception by G. Sukhobrus for us is the fact that, the legends and the retellings can be composed about the same event or the same person. That is why, according to the researcher, there exist the conditional character of the division between legends and

${ }^{10}$ Украинские народные предания / собрал П. Кулиш. Москва, 1847. Кн. 1. 92 с.

11 Сухобрус Г. Легенди і перекази. Украйнська народна поетична mворчість. Київ : Радянська школа, 1965. С. 163. 
retellings ${ }^{12}$, and so, the event or the hero can't be taken as the factors, which differentiate the genre, which need the great amount of changes and specifications.

Along with the names of real historical personalities, the researcher frequently uses the term "image", which is important in the context of modern disputes about the nature of the folklore genres, but does not develop the thought about the character of the correlation between name and image of the retelling's heroes. Developing these observations, it should be noted that, the folklore image of the historical person is not identical to this person, and so in the literary work of non-fairy prose it goes not about famous people, but about their "double", the characteristics and the biography (or some elements) of which are created by the laws of the folklore and the genre tradition. The heroes' images with the names of historical personalities and the mechanisms of their creation in legends and retellings are different, but these mechanisms are similar in retellings and historical songs.

The significant event in the history of the modern Ukrainian folklore study appeared the academic publishing of Ukrainian legends and retellings with the preface by O. Dey, where the main criteria of the genre specificity is "the level of trustworthiness $<\ldots>$ of representations, the character of the attitude towards the reality, or, in other words, the specific gravity of the true, real, possible or, vice versa, - fictional, fantastic and unbelievable. The first is the attributive dominant of the retelling, and the second - of the legend"13. As to such definition, it should be said that, in the traditional surrounding both, the legend and the retelling, were perceived as the story about the real, possible things. The orientation of the legend to the past and extrapolation of the miraculous in it, assured only the fundamental difference of the ordinariness from things which were earlier, it contributed to the idealization and mythologization of the history and historical personalities. (This question was studied earlier ${ }^{14}$ ).

12 Сухобрус Г. Легенди і перекази. Українська народна поетична творчість. Київ : Радянська школа, 1965. С. 165.

13 Дей О. Легенди та перекази. Легенди та перекази. Київ : Наукова думка, 1985. С. 7.

14 Павленко I. Міфологізація запорожців в легендах Нижньої Наддніпрянщини (деякі спостереження). Література в контексті культури : збірка наукових праць. Дніпропетровськ : Вид-во Дніпропетровського університету, 2002. Вип. 8. С. 8-18. 
Accroding to V. Davydiuk, "the genre peculiarities of the retelling $<\ldots>1$ ) realism (both in the nature of the characters, and in the structure of motives); 2) the outer form of the expression of the epic position, the complete absence of the connection with the witness on the basis of the general value of events, which are represented in the literary work; 3) khronicat or the embryonic form of the fabulat; 4) the indication of comparatively recent time; 5) the open form of the plot representation; 6 ) the absence of bright characters" ${ }^{\prime 5}$. But, the principle of the reality of the folklore literary work itself needs the argumentation and fundamental explanation. The time in retelling may be different, but it always will be the past. The epic distance may be measured both by decades and centuries, which is depicted in Ya. Novitskyi's and a little bit later in D. Yavornytsky's retellings, which were written "from grandfathers" at the "Cossacks' site of fires", about the death of some prince or king on the Purisoviy islands ("People who sit told, that someday two kings were fighting there, and one of their army has fallen. It was long ago" "16), (this motive was fixed also in the notes by V. Suprunenko ${ }^{17}$ ), where the mass burial of the army of Sviatoslav's times. In V. Sokol's works there are some notes, dated at the border of $\mathrm{XX}$ and $\mathrm{XXI}^{\text {st }}$ centuries, about the revenge of the princess/tsarina/mistress, which occurred at the former drevlyans lands and are the echo of the famous event, which is connected with Olga's revenge for Igor's death ${ }^{18}$. IS it possible to consider the epic distance in one thousand years as insignificant?

Observations on the retellings give the material for the statement that, they exist in the form of khronicat and fabulat, not "embryonic", but of full value. The character of the correlation between these forms may be different: the khronicat may become the initial from of the fabulat and, at the same time, it may be the result of its reduction or simple forgetting. Sometimes, the existence of the khronicat is caused by the character of the communicative situation and is the deliberate reduction of the literary work, as both the storyteller and the listener have the same or very similar level of information about the event (person, geographical object), the same knowledge does not require amplification of the story. Depending on the situation, the khronicat may be developed into the fabulat, rumor,

15 Давидюк В. Українська міфологічна легенда : монографія. Львів : Світ, 1992.

16 Новицкий Я. С берегов Днепра (Очерки Запорожья). Сборник статей Екатеринославского научного общества по изучению края. Екатеринослав, 1905. C. 131.

${ }^{17}$ Супруненко В. Дніпрові пороги. Субота +. 2005. № 31 (337). С. 8.

18 Історичні перекази українців. Львів : Видавництво Л. Коць, 2003. С. 15. 
hearsay, and separate motive may be structured as the plot-organized literary work. And also the fabulat may be reduced into khronicat. The khronicat about the drowned golden horse is widespread on the banks of the river Konka. The plot-organized retelling about how, when and why it happened, is possible to fix only from the most talented storytellers. The same is about the treasure by Makhno in the river Molochna.

In V. Sokol's works the retelling is considered as "the prose nationalpoetic work about historical personalities and events, the witness of which the storyteller was not"19, it necessary concerns historical personalities, despite the degree of fantasy ${ }^{20}$. Thus, the dominant genrecreating trait is the type of hero. Such approach of the researcher to the identification of the genre specificity does not include such components of the literary world as time and space and also the character of correlation of the event which is possible. As a result of it the set of texts, which are assumed by him as retellings, is intensely broadens, that was represented in the collections published by him.

At the same time the hero in the folklore usually represents the name with motives and plots grouped around. These motives may have different forms of amplification, so one name, which could belong to the historical personality, and later became the name of the folklore heroes, can be connected both with legendary (mythologized motives) and historical-heroic motives. So, characters with the same name can appear both as heroes of the legend and as heroes of the retelling.

The analysis of the folklore and folkloristic discourses, the observation on the dynamics of the development of the Ukrainian nontale prose give possibility to claim that, genre-creating and genredifferentiating (when it goes about the adjoining genres of the non-tale prose) for the retelling is the fact that, it is mostly directed at preserving the historical memory about events or historical personalities by the community, when the main event and hero's characteristics are caused by the sphere of real and possible. Everything, which was possible in the past, is potentially possible in present, so it was, is and can be in future.

So, the definition, to which we appeal, is the next. Retellings are the literary works of folklore non-tale prose about important (from the point

${ }^{19}$ Сокіл В. Народні легенди та перекази українців Карпат. Київ : Наукова думка, 1995. С. 22.

${ }^{20}$ Сокіл В. Топонімічна проза : жанрова і сюжетно-тематична специфіка. Писана керниця : Топонімічні легенди та перекази украӥнців Карпат. Львів : Інститут народознавства НАНУ, 1994. С. 8. 
of view of the historical, local community or some family) events and personalities of the past, which represent national and historical understanding of the past, its specific periods or separate events. The fiction crosses the borders of the real or potentially possible. The events of the past are placed in the real chronotope.

The epic songs became one of the first folklore literary objects, which were collected and studied, but, up to this moment, there is no general understanding about the question of the genre specificity of the historical song, as well as of the retelling. In fact, there were no attempts to analyze the pragmatics and literary world of the genre and to compare historical songs with literary works of prose epic literature. But, as a rule, they are usually compared with elegies and ballads.

One of the first attempts to define historical songs belongs to I. Sreznevskyi. Describing the character of texts selection, he explained that he publishes "Songs and elegies properly historical, i.e. those, whose subject is the story about events or historical personalities"

In the "Preface" to the famous collection by M. Dragomanov and $\mathrm{V}$. Antonovich two different definitions of historical songs are presented: the first one describes the historical song as "those, which describe people and events, mostly known from written sources and those, which played an important role in the nations" history"22, "all songs which reflected the change of the social order $\left\langle\ldots>\right.$ of the nation" ${ }^{23}$. The second definition (from the point of view of the authors, is not very clear, which should be kept in mind) highly passes the limits of one genre. The contradictions, which are peculiar to the further solution of the question about the genre nature of the historical songs, are laid in this particular work, as, the formulated above definitions correlate with each other as the general and the partial.

The significant contribution into the study of the Ukrainian historical songs was the academic publication in 1961, in the preface to which the authors claim that, "The historical song is such literary work of the national poetry, which correctly depicts pictures of the historical reality. This is a literary chronicle, which recreates not always reliable, but surely typical pictures of nation's social life of certain period. $<\ldots>$ mainly, it is the big in size literary work, with clear stanza, rhyme and melody structure

21 Запорожская старина И. Срезневского. Харьков, 1833. Ч. 1. С. 23.

22 Исторические песни малорусского народа с объяснениями Вл. Антоновича и М. Драгоманова. Киев : Типография М.П. Фрица, 1874. Т. 1. С. І.

${ }^{23}$ Там само. С. III. 
and correct rhyming" ${ }^{24}$. So, the content and the rhythm-forming are considered as the genre-creating traits. As far as literary works with different social functions, character of the world outlook and completion can match this definition, the named above factors are not enough.

It is obvious that, all the observations are based on the concrete empirical material, but they are from different meanings of the term "historical song" and from opinions about different literary works according to the time of their origin and record.

The controversy of the term and its definitions is based, first of all, on the essential difference in poetics and level of concreteness/generalization in literary works, the content of which correlates with different epochs and periods of the domestic history. The epic distance (the time of the recording in relation to the date of the initial event) is essential for the characteristic of concrete songs and their cycles. The song, which was recorded some years after the event may substantially differ from the literary work about the same event or person, recorded in some centuries. That is why the question about the origin of the historical songs is so significant for the determination of their genre specificity.

Ya. Holovatskyi was the first, who addressed to this question in the Ukrainian folklore study. Analyzing epic literary works he concludes that, all of them originate during the event, which is described in them (emphasizes M. Voznyak ${ }^{25}$ ). Later the same thought was expressed by P. $\mathrm{Kulish}^{26}$. V. Hnatiuk considered that, national songs are created "during the event or not long after it" 27 . This thesis is actualized in the works of the researchers of the folklore study of the second half of the $\mathrm{XX}^{\text {th }}$ century. From I. Berezovskyi's point of view there are concrete facts in the basis of the historical songs, which "were created, as a rule, by the participators (or alive witnesses) of the event, who recorded these

24 Березовський I., Родіна М., Хоменко В. Історичні пісні українського народу. Історичні пісні / упоряд. І. Березовський, М. Родіна, В. Хоменко ; нотн. матеріал упор. А. Гуменюк ; за ред. М. Рильського, К. Гуслистого. Київ : Вид-во Академії наук Української РСР, 1961.

Ч. 1. С. 109 .

25 Возняк М. Століття «Зорі» Маркіяна Шашкевича. Львів, 1936.

26 Записки о Южной Руси : в 2-х т. Издал П. Кулиш. Киев : Дніпро, 1994. Т. 1, 2.719 с. [Репринтное издание 1856-1857 гг.]. С. 178-180.

${ }^{27}$ Гнатюк В. Вибрані статті про народну творчість. Київ : Наукова думка, 1966. C. 87. 
events via words and music in the smallest details" 28 . In works by S. Hrytsa are considered as poligenre literary works. "The only criterion of their joining is the historical thematic. In the song folklore this thematic is concentrated in different genres $\langle\ldots>$. Being the secondary, it represents only their attributive characteristics. Conceptual is the thesis that, the more time separates songs from the described events, the more generalizations and typifications there will occur and vice versa, the nearer the described event is to us, the more historical concretization and trustworthiness it will be characterized by" ${ }^{\prime 2}$. From myself, I can add that, along with the process of episation, the preserving of variants, which are related to the initial text of the literary work and the initial world view is possible.

Our observations assure that, the rhythm-forming of historical songs facilitate the fixing of the text, sometimes even at the level of characters and the nature of the correlation hero/storyteller, as very often the songs with the epic distance in 1,5-2 centuries were found, where the hero and the storyteller merged and the story is told from the first person ${ }^{30}$. Such thing never happens in retellings, as the storyteller never correlates himself with the hero.

Both retellings and historical songs are created after some event and only with some time they transform from the stories about the modern time into historical literary works. This is not the initial trait of the genre, but its reaction to the movement of time and to the character of the primary text's perception by the storytellers. With the change of their consciousness and knowledge about the event, the attitude towards it alters, as well as the character of its representation. In the process of polishing of the literary work, subjective evaluation is gradually changing by the objective one, authentic elements are changing into typical, usually generalized ones. Without regard to the character of the further transformation, the historical song (as a literary genre) is the dynamic system, which has its own world view, which does not depend on the time of the creation, social-domestic functions, and rhythmcreation and is based on the notional-historical memory. In the scope of

28 Березовський I. Народ про свою історію. Історичні пісні. Київ : Радянський письменник, 1970. С. 10.

${ }^{29}$ Грица С. Украинская песенная эпика : монография. Москва : Советский композитор, 1990. С. 117.

${ }^{30}$ Павленко І., Козленко Н. Я / ми / вони в історичних піснях Нижньої Наддніпрянщини. Вісник Запорізького національного університету. Серія «Філологічні науки». 2017. № 1. С. 21-28. 
song texts about the past, the unity of the world view correlates with the common social functions, the resemblance of the rhythm-creation and the character of its adoption and translation. Historical songs are based on the events, which mean fable and plot. According to all above mentioned the definition of the historical song may be the next. Historical songs are folklore, syncretic (verbal-musical) song narratives, which depict the national and historical understanding of the past, it's certain stages or some separate events, memory about people and representatives of some specific society, are characterized by precise rhythmical organization and may be performed both as solo and in chorus.

\section{The past and the specificity of its interpretation in the folklore narratives}

In the folklore material the appeal to the problem of the correlation between the retelling and historical songs is always actualized. The same person, very often, perform the historical song and the retelling about the same event or person, where the prose work becomes the, so called, form of commenting. The prose insertions are usually presented in the song literary work, as if recollecting some lost moments, but, at the same time, both prose and song literary works, which are recorded from different people, are mutually supplementing each other and making the single poligenre cycle.

As far as historical songs and retellings usually appeal to the same events and heroes in the national memory, the character of the genetic relation of the historical songs and prose genres of the folklore repeatedly attracted researchers' attention.

The first, who raised the question about the correlation between the retellings and historical songs about Paliy, in the Ukrainian folklore study, on the basis of the literary works of different genres, was V. Kallash, who had the opposite point of view, as he thought that retelling are the result of the collapse of historical songs ${ }^{31}$.

There are some interesting thoughts about this fact in the Russian folklore study, made by V. Sokolova. The researcher proceeds from the fact that, historical songs and retelling originate at the same time, exist at the same surrounding, and are united into the cycles around one image or one event ${ }^{32}$. At the same time she mentions that, despite thematic and

${ }^{31}$ Каллаш В. Палий и Мазепа в народной поэзии. Москва, 1889. 44 с.

32 Соколова В. Русские исторические предания : монография. Москва : Наука, 1970. С. 228-231. 
ideological propinquity, each genre has its own peculiarities, which is also relevant to our observations.

In general, we agree with such point of view, but it should be noted that, our understanding of the genre specificity of the retelling brings some amendments in it, additionally, the material, which was studied in the diachrony, makes it possible to broaden and correct it.

The historical song, as a rule, correlates with the retelling in the result of identical or the most similar attitude towards the reality, the character of the historism, the representation of the hero, time and space. Like retellings, this is a narrative genre, these literary works often have plot and are topically-organized, but, in most cases, the plot and the plot development are generally given, the attention is paid mostly to the climax and denouement. Genres under analysis differ both according to formal characteristics, such as rhythm-creating, verbal-musical syncretism, and circumstances of origin, ways of translation, and, sometimes, some additional functions.

It must be noted that, retellings and historical songs, which occur in one region, may be described by the similar plot or characteristics (for example, the ruining of the Sich), but, there are also motives, which are peculiar only to the national prose. For example, there is no motive of treasure in historical songs, which is widespread in the folklore prose of the region. Toponymic motives are also absent in the historical songs. The «biography» of the hero is rarely present (the historical song only gives the story about his participation in some event, gives only one episode). Even the scope of historical songs (at least, in the region under analysis) never created the cycle of literary works about the life and activity of the hero. For example, in different texts of Nizhnya Naddnipryanshchyna diverse "events" of the "biography" of Paliy, Sirko, Kalnishevskyi, Makhno etc. are described. In general, the quantity of motives and plots in retellings is more rich than in historical songs, which can be explained both by the way of preserving and transmission of different types of folklore narratives, and by the conditions of their origin.

For the creating of the retelling the event, which was reflected in the memory of the nation, is important. The information about it may be preserved as "folded up" to the semantic core, and during the process of translation each time the new text, which is open to all novelties, is presented. That is why, different loans may occur here. But, the main thing is that, the retelling, as a rule, actively shows the conception of the past, the understanding of the generation-translator, but not of participants and witnesses of the event. 
The oral folk prose has its own laws of rendering, because, the story is inspired both by outer and inner circumstances: the explanation of the natural artifact, the information about the facts, which are interesting for the listener, storyteller etc.; in different situations, depending on the character of the audience and the erudition and talent of the storyteller, the literary work can sound differently; there may be different level of excavation into the topic in different circumstances and types of communication.

The "witness" in retellings is the first storyteller. The next are recipients and translator, who perceive narration as intellectual information, story about something, which occurred in reality, and modify it according to the peculiarities of memory, relation to the past. But, first of all, depending on the character of communicative event and recipients (on whom, mostly, the communicative act depends).

The personal "solo" character of the representation contributes to the free and restricted, only with the tradition, modification. Each new generation has new, modernized or extended preceding and additional information.

At the process of representation, the storyteller is the expert, in the field which is unknown to the listeners, so the level of his cultural competence, at least during the process of telling the story, is perceived as higher, and as such, that can be shared.

The oral prose narrative is corrected by the listener's upcoming experience, is correlated with his other knowledge about the event and folklore traditions. That is why, when he himself, becomes the storyteller, he conveys (as a rule, in the frames of the genre canon) the result of his own intellectual activity, perception, remembering and interpretation, but not the text, which was once heard.

For the originating and long functioning of the song, the combination of several factors should be presented: the bright event; talented witnesses or participants; the knowledge about the folklore tradition; the interest of the coeval; the actuality (or informative character) of the literary work for the descendants. If some of these factors are absent, the literary work about some event may not be presented. At best, the earlier created song will be transformed, or the event will still not be praised and its memory will live only in the folklore prose narrative or will be lost.

At one time V. Propp admitted that, sometimes the choice of events in historical songs is strange, as "minor, non-significant events are sometimes praised, while the most significant, important events $\langle\ldots\rangle$ of 
the history are sometimes not revealed by the historical songs" ${ }^{\text {"33. }}$. Observing the character of the representation of the history in the folklore, B. Putilov explained such phenomenon by the fact that, "the reality generalizes not from the side, but from the inside" 34 ."Selected", sense-evoking become events, which strike the mind and provoke new emotions. And only those can be characterized as such, in which the nation plays the active role, and which are considered as crucial. The presence/absence of talented witnesses or participants, who create the text, which was later changed or transformed, can be explained by the generally known fact that, there were song works not about all significant historical events.

As long as in the process of transmission the text of the historical song is memorized almost entirely (thanks to the rhythmic organization and the form of representation), the level of later "changes" of the event or hero's biography is a lot lower, than in the retelling. At the same time the possibility of penetration of initially foreign plot peculiarities and motives is here restricted. The historical song is creating as the immediate reaction at the vent in the text, which is reduced, and exists in more or less stable (in the comparison to the prose folklore literary work) form. So, the comprehension of the event or activity of the hero by the descendants does not develop into independent texts, and motives, which are generated by them, almost do not get into historical songs.

Historical songs are performed both alone (as solo), which is characteristic of the national prose literary work, and collectively - such presentation of the national prose literary work is impossible. Sometimes several people may take part in the process of telling the story, but each of them appeal to his own "portion" of information, while during the choral singing the general information for each performer is stable and equal (or almost equal) for everybody ${ }^{35}$.

At the process of performing of historical songs it is necessary not only to actualize the historical information, which should be presented in the text, but also to show the existence of the collective knowledge of the literary work. It is the mean of ethical and cultural self-identification of

33 Пропп В. Поэтика фольклора : собрание трудов. Москва : Лабиринт, 1998. C. 331.

34 Путилов Б. Историко-фольклорный процесс и эстетика фольклора. Проблемы фольклора. Москва : Наука, 1975. С. 17.

35 Адоньева С. Своя чужая речь : фольклор в свете прагматики. Фольклор инародная культура / Б. Путилов. In memoriam. Санкт-Петербург : Петербургское востоковедение, 2003. С. 239-251. 
the person and group of performers, and the creation of the feeling of entity, at least at the emotional level, assures the membership to the same socio-cultural group and helps to differentiate the representatives of the society from "other" or "foreign" ones.

This factor causes the characteristic trait of historical songs: along with functions of preserving and fixation of the historical memory (mnemonic and informative), rendering of the moral experience of the generations and orientation at the ethical basis of their existence (didactic), which are peculiar to the national oral prose in general, they are characterized by functions of grouping of the collective (consolidating) and stabilization of its habitus (regulatory. normative

The process of rendering of retellings is, mostly, individualized, dependent on the peculiarities of memory and interpretative abilities of concrete person-storyteller ${ }^{36}$. Unlike prose narrative genres, where the interpretational beginning can be revealed at any stage - at the process of creating, understanding and performing, in historical songs it usually occurs in the process of creation and is less (or just less expressed) in the process of understanding and performing. Structurally and rhythmically fixed information sometimes makes it possible some variations (and it is obvious, as understanding of any text of culture depends on the level of cultural competence of participants of the context of the communicative event - the performing of the folklore literary work) and interpretation, but verbal interpretations and variations in comparison to the prose literary works are insignificant.

The fixing of the textual changes takes place on condition of "agreement" with the collective (do they perceive or not the innovations, and so they agree to sing in such a way), because in the case of nonagreement the chorus singing became impossible.

More or less stable text contributes to the fixed content and evaluation, that is why the necessity in the additional interpretation, prose comment appears, and the performing of the song accompanies by the retelling, which is more mobile in adaptation in time and space. The retelling as the type of historical songs' interpretation is the evidence of the absolute cultural competence of the storyteller. The addresseerecipient of such contamination - the song plus the retelling - is less knowing (or not informed at all) about the folklore tradition of the society or local collective, about which past it goes, person. The singers

36 Чейф У. Память и верблизация прошлого опыта. Новое в зарубежной лингвистике. Москва : Радуга, 1983. 
commented and comment till now the texts of songs for those, who record them. The combination of the literary works of the equal genres is based not on the tradition, but on the situation and different levels of storytellers and listeners' erudition.

\section{CONCLUSIONS}

The conducted study allows claiming that, the retelling is the product of the national-historical thinking, which aims to preserve the memory about significant and insignificant events for the society. Properly "historical memory" is the result of the enduring existence of the literary work, which occurs as the reaction to the modern event, and only storytellers and descendants, later translators, will understand it as historical. The similar "metamorphosis" of the literary work about the modern times into the historical one happens in historical songs, the genre, which is due to the character of the attitude to the past is typologically related to retellings. In songs the psychological reaction at the event and some story about its course or some separate parts is fixed with the help of rhythm and melody. And so there is less possibility to transform it in comparison to the prose material, but, obviously, it also may be changed in time and space. Each recipient and translator adds his/her own understanding about the past into the prose literary work, and so the variety is inevitable with each performing. Possibilities of further subjectivisation in the interpretation of the event are in the basis of the first stories about it, as each transformation of the event into the text is subjective.

For both analyzed scopes of texts the same traits in the relation to the past and its narrativisation are characteristic, which were presented in the expression of the national-historical way of thinking: similar choice of events (prominent or, at least, important for some group of people events and persons of the past); orientation at those events, which have already became history, without interference into the present; interest in local and regional history; efforts to describe truly (or with maximum proximity) the events of the past; constant actualization of the informative and mnemonic functions. They represent the past in that way as it is remembered or wanted to be remembered by the nation. The depth of the historical memory in retellings may reach one centuries, while the epic distance of historical songs may reach 3-4 centuries.

The modus of understanding and interpretation of the past may change in accordance with requests, interests and readiness for perception. In such a way, are almost lost historical songs and retellings 
about Zaporizhzhya and Zaporizhzhian Cossacks on the territory of Nizhnya Naddnipryanshchyna: during the last third of the $19^{\text {th }}$ century they were performed by "grandfathers", but were not copied by their children and grandchildren.

\section{SUMMARY}

This articles deals with the character of the formation and definition of the retelling and historical songs in the modern folkloristic discourse, with the reception of the literary works of these genres, the specificity of the reproduction of past, in particular, in them. It was suggested to study the genre as the whole of genre-creating and companion factors. Based on it there were proposed several own definitions, which include such criteria as the world view (actant + time + space), character of the reproduced events and the relation towards them, functions and the way of their translation, specific forms of literary work's transformation and information, which is represented in it. General (basis on the nationalhistorical worldview; social functions; rendering to the real events and names of the historical people, which were famous in specific region; the development of the plot or plot situation from the initial impressions of witnesses or participants; the reliability of the chronotope; the transformation of the text depending on the perception of the past by the storytellers etc.) and specific (prose/poetical works; only verbal/verbalmusical literary works; solo/chorus performing; different fixation of the text, and information in prose and song literary works; outer position of storyteller of the retelling, relating to the event, and the possibility of identification of the object and subject in songs) traits of the genres under analysis were revealed, and also in the relation to the past and its narrativisation.

\section{References}

1. Адоньева С. Своя чужая речь : фольклор в свете прагматики. Фольклор и народная культура / Б. Путилов. In memoriam. Санкт-Петербург : Петербургское востоковедение, 2003. С. 239-251.

2. Березовський I. Народ про свою історію. Історичні пісні. Київ : Радянський письменник, 1970. С. 5-26.

3. Березовський I., Родіна М., Хоменко В. Історичні пісні українського народу. Історичні nicнi. Київ : Вид-во Академії наук Української РСР, 1961. С. 7-62. 
4. Будівський П. Олекса Довбуш в історії, фольклорі та літературі (проблеми історичної та художньої правди) : монографія. Київ : Бланк-Сервіс, 1999. 496 с.

5. Возняк М. Століття «Зорі» Маркіяна Шашкевича. Львів, 1936. Ч. 1. C. 109.

6. Гнатюк В. Вибрані статті про народну творчість. Київ : Наукова думка, 1966. 322 с.

7. Грица С. Украинская песенная эпика : монография. Москва : Советский композитор, 1990. 262 с.

8. Давидюк В. Голос німого дзвона. Золота скриня: народні легенди перекази з Північної Волині й Західного Полісся. Луцьк : Вежа, 1996. С. 3-9.

9. Давидюк В. Українська міфологічна легенда : монографія. Львів : Світ, 1992. 176 с.

10.Дей О. Легенди та перекази. Легенди та перекази. Київ : Наукова думка, 1985. С. 7-35.

11. Джерела про зруйнування Запорозької Січі / уклав Василь Сокіл. Львів : Афіша, 2005. 127 с.

12.Дунаєвська Л. Легенди та перекази. Українська народнопоетична творчість / М. Грицай, В. Бойко, Л. Дунаєвська. Київ : Вища школа, 1985. С. 242-253.

13.Записки о Южной Руси : в 2-х т. Издал П. Кулиш. Киев : Дніпро, 1994. Т. 1, 2. 719 с. [Репринтное издание 1856-1857 гг.].

14.Запорожская старина И. Срезневского. Харьков, 1833. Ч. 1. 162 с. ; Ч. 2.1. Харьков, 1834. 85 с. ; Ч. 2.2. Харьков, 1835. 166 с. ; Ч. 3. Харьков, 1838. 166 с.

15.Исторические песни малорусского народа с объяснениями Вл. Антоновича и М. Драгоманова. Киев : Типография М.П. Фрица, 1874 T. 1. XXIV.

16.Історичні перекази українців. Зібр. та опрацював Василь Сокіл. Львів: Вид-во М. Коць, 2003. 327 с.

17.Каллаш В. Палий и Мазепа в народной поэзии. Москва, 1889. $44 \mathrm{c.}$

18.Кейда Ф., Мишанич С. Народні месники України у фольклорі : монографія. Донецьк : Кассіопея, 1998. 113 с.

19.Кейда Федір. Український фольклор про гайдамаччину : монографія. Київ : Вирій, 1999. 240 с.

20.Коновалова М. Гетьман Мазепа у фольклорі і літературі : автореф. дис. ... канд. філол. наук. Львів, 2001. 16 с.

21.Легенди та перекази. Київ : Наукова думка, 1985. 400 с. 
22. Медведев П. (Бахтин М.). Формальный метод в литературоведении : Критическое введение в социологическую поэтику. Москва : Лабиринт, 2003. 193 с. (Бахтин под маской. Вып. 2).

23. Мишанич С., Кейда Ф. Гайдамаки та опришки виразники національно-визвольних змагань українського народу. Донецьк : Касіопея, 1995. 101 с.

24.Народ про Довбуша : збірник фольклорних творів. Київ : Наукова думка, 1965. 304 с.

25.Народ про Кармелюка : збірник фольклорних творів. Київ : Вид-во Академії наук Української РСР, 1961. 276 с.

26. Народні легенди та перекази українців Карпат. Київ : Наукова думка, 1995. 157 с.

27. Новицкий Я. С берегов Днепра (Очерки Запорожья). Сборник статей Екатеринославского научного общества по изучению края. Екатеринослав, 1905. С. 11-205.

28.Павленко I. Історичні пісні Запорожжя: регіональні особливості та шляхи розвитку : монографія. Запоріжжя : Тандем-У, 2003. $202 \mathrm{c}$.

29. Павленко I. Легенда та переказ в українському фольклорі: до проблеми дефініцій. Мова $і$ культура : науковий журнал. Київ : Видавничий дім Дмитра Бураго, 2007. Вип. 9. Т. VIII (96). С. 5-13.

30. Павленко I. Легенди та перекази Нижньої Наддніпрянщини: буття у просторі та часі : монографія. Запоріжжя : ЗНУ, 2006. 243 с.

31.Павленко I. Міфологізація запорожців в легендах Нижньої Наддніпрянщини (деякі спостереження). Література в контексті культури : збірка наукових праць. Дніпропетровськ : Вид-во Дніпропетровського університету, 2002. Вип. 8. С. 8-18.

32. Павленко І., Козленко Н. Я / ми / вони в історичних піснях Нижньої Наддніпрянщини. Вісник Запорізького національного університету. Філологічні науки. 2017. № 1. С. 21-28.

33. Писана керниця : топонімічні легенди та перекази українців Карпат / зібр. і впоряд. Василь Сокіл. Львів : Інститут народознавства НАН України, 1994. 205 с.

34.Пропп В. Поэтика фольклора: собрание трудов. Москва : Лабиринт, 1998. 265 с.

35.Путилов Б. Историко-фольклорный процесс и эстетика фольклора. Проблемы фольклора. Москва : Наука, 1975. С. 12-20.

36. Путилов Б. Типология фольклорного историзма. Типология народного эпоса : сборник статей. Москва : Наука, 1975. С. 164-181. 
37.Січова скарбниця : легенди та перекази Нижньої Наддніпрянщини / упор. В. Чабаненко. Запоріжжя : ЗДУ, 1999. 392 с.

38. Сокіл В. Топонімічна проза: жанрова і сюжетно-тематична специфіка. Писана керниця : Топонімічні легенди та перекази українців Карпат. Львів : Інститут народознавства НАНУ, 1994. C. 7-25.

39. Сокіл В. Народні легенди та перекази українців Карпат. Київ : Наукова думка, 1995.158 с.

40.Соколова В. Русские исторические предания : монография. Москва : Наука, 1970. 288 с.

41.Супруненко В. Дніпрові пороги. Субота +. 2005. № 31 (337). C. 8.

42.Сухобрус Г. Легенди i перекази. Українська народна поетична творчість. Київ : Радянська школа, 1965. С. 161-171.

43. Украинские народные предания. Собрал П. Кулиш. Москва, 1847. Кн. 1.92 c.

44.Українські думи та історичні пісні. Москва : Укрдержвидав, 1944.

45.Українські народні думи та історичні пісні. Київ : Вид-во АН УРСР, 1955. 655 с.

46.Українські народні казки, легенди, анекдоти: хрестоматія. Київ : Держлітвидав, 1957. 543 с.

47.Ходили опришки : збірник. Ужгород : Карпати, 1983. 384 с.

48. Хоменко В. Історичні пісні. Украӥнська народна поетична творчість. Київ : Радянська школа, 1965. С. 209-34.

49. Чейф У. Память и вербализация прошлого опыта. Новое в зарубежной лингвистике. Москва : Радуга, 1983. С. 35-4.

Information about the author: Pavlenko Iryna Yakivna, Doctor of Philology, Professor, Head of the Department of Slavic Philology Zaporizhzhya National University 66, Zhukovsky str., Zaporizhzhya, 69600, Ukraine 